\title{
DESAIN PELATIHAN, DUKUNGAN ORGANISASIONAL, DUKUNGAN SUPERVISOR DAN SELF-EFFICACY SEBAGAI FAKTOR PENENTU KEEFEKTIFAN TRANSFER PELATIHAN
}

\author{
Eko Hariyanto \\ Ratno Purnomo \\ Icuk Rangga Bawono \\ Universitas Jenderal Soedirman, Purwokerto \\ e-mail: cukycutes@yahoo.com; cukycutee@gmail.com
}

\begin{abstract}
This study examined the effects of effective design training, organizational support, supervisor support and self-efficacy on transfer of training effectiveness in public hospital in Banyumas. Respondents were nurses in five public hospital located in Banyumas $(N=346)$. Result of the multiple regression analysis showed that effective design and training retention had significant and positive effects on self-efficacy and transfer of training effectiveness. Besides that, self-efficacy itself had a significant and positive effects on transfer of training effectiveness. Other factors, organizational support and supervisor support had no significant effect on self-efficacy and transfer of training effectiveness. Implications for future research and practice are discussed.
\end{abstract}

Keywords: training design, self-efficacy, transfer of training

\begin{abstract}
Abstrak
Penelitian ini bertujuan untuk menguji pengaruh beberapa faktor yang menjadi anteseden keefektifan transfer pelatihan. Faktor anteseden tersebut adalah desain pelatihan efektif, dukungan organisasional, dukungan supervisor, dan self-efficacy. Penelitian dilakukan di lima rumah sakit umum daerah di wilayah Banyumas dan sekitarnya. Responden penelitian ini adalah perawat yang pernah mengikuti pelatihan $(\mathrm{N}=346)$. Hasil analisis dengan menggunakan multiple regression analysis menunjukan bahwa desain pelatihan efektif, retensi pelatihan, dan self-efficacy memiliki pengaruh signifikan terhadap kefektifan transfer pelatihan. Selain itu, hasil penelitian juga menunjukan bahwa self-efficacy ditentukan oleh desain pelatihan efektif dan retensi pelatihan. Di sisi lain, dukungan organisasional dan dukungan supervisor tidak memiliki pengaruh signifikan terhadap self-efficacy dan kefektifan transfer pelatihan. Pembahasan dan saran untuk penelitian selanjutnya diuraikan di bagian akhir artikel.
\end{abstract}

Kata kunci: desain pelatihan, self-efficacy, transfer pelatihan

\section{PENDAHULUAN}

Pembangunan manusia seutuhnya menjadi salah satu titik tekan program pemerintahan selama lima tahun ke depan, karena memang kualitas bangsa ditentukan oleh kualitas manusianya. Pembangunan manusia menjadi perhatian utama karena kualitas manusia adalah aset berharga yang akan menentukan keberhasilan pembangunan semua sektor. Keberhasilan pembangunan manusia itu sendiri harus memperhatikan berbagai aspek penting seperti pendidikan, kesejahteraan, dan kesehatan. Aktivitas peningkatan kualitas pendidikan, kesejahteraan dan kesehatan dapat dilakukan baik pada skala nasional maupun regional. Aktivitas peningkatan kesehatan masyarakat misalnya, dapat dilakukan di tingkat regional melalui pelayanan kesehatan di berbagai instansi publik seperti puskesmas dan rumah sakit umum daerah. Artinya, kualitas pelayanan kesehatan kepada masyarakat di daerah akan menentukan kualitas kesehatan itu sendiri dan dalam jangka 
panjang akan mendukung keberhasilan pembangunan manusia, baik secara regional maupun nasional.

Namun demikian, pelayanan kesehatan masyarakat di daerah masih menyimpan beberapa permasalahan, diantaranya adalah masih rendahnya produktivitas tenaga kerja di sektor kesehatan tersebut. Salah satu indikasinya adalah belum maksimalnya pelayanan kesehatan masyarakat yang dilakukan di rumah sakit umum daerah (Mustofa dan Darmawan, 2009). Oleh karena itu diperlukan usaha-usaha untuk meningkatkan produktivitas kerja tersebut. Salah satu diantaranya adalah dengan menyelenggarakan program pelatihan. Pelatihan merupakan salah satu aktivitas penting untuk pengembangan sumber daya manusia sebuah organisasi (Holton et al., 2000). Namun, permasalahannya adalah banyak program pelatihan yang tidak efektif sehingga tidak mampu meningkatkan kualitas dan produktivitas tenaga kerja sektor kesehatan. Ketidakefektifan terjadi karena pelatihan tidak dirancang dengan tepat dan tidak direalisasikan atau ditransfer dalam pekerjaan sehari-hari (Velada et al., 2008; Saks and Belcourt, 2006; Colquitt et al., 2000; Burke and Baldwin, 1999). Oleh karena itu, diperlukan pengembangan model transfer pelatihan yang mempertimbangkan berbagai faktor penting sehingga pelatihan dapat efektif meningkatkan produktivitas kerja. Faktor-faktor penting dalam rancangan pelatihan efektif berdasarkan hasil penelitian sebelumnya antara lain adalah karakteristik individu, desain pelatihan yang tepat, dan dukungan lingkungan kerja (Baldwin and Ford, 1988; Scaduto et al., 2008, dan Velada et al., 2008). Berbagai penelitian sebelumnya tersebut dilakukan pada organisasi bisnis swasta, dan belum dilakukan di organisasi publik milik pemerintah. Penelitian ini berusaha untuk menguji berbagai faktor penentu keefektifan transfer pelatihan dengan menggunakan latar belakang (setting) organisasi publik milik pemerintah yaitu rumah sakit umum daerah. Faktor-faktor yang dipilih didasarkan pada hasil penelitian sebelumnya tersebut.

Tuntutan untuk memberikan pelayanan yang prima kepada masyarakat, menjadikan rumah sakit umum daerah terus berusaha meningkatkan kinerjanya. Salah satu faktor penting penentu kinerja adalah kualitas sumberdaya manusia yang dikembangkan melalui pro- gram pelatihan. Permasalahannya adalah adanya kecenderungan program pelatihan pada organisasi sektor publik itu hanya dijadikan formalitas saja, padahal pelatihan memainkan peran yang penting bagi terciptanya kualitas sumberdaya manusia. Selain itu, transfer pelatihan sebagai salah satu bagian penting keberhasilan pelatihan tidak berjalan sebagaimana mestinya. Dengan kata lain, pelatihan tidak meningkatkan produktivitas kerja. Pelatihan akan berdampak positif pada peningkatan produktifitas kerja apabila ketrampilan, pengetahuan, dan pengalaman yang diperoleh selama pelatihan digunakan dalam pekerjaan sehari-hari (Facteau et al., 1995).

\section{KAJIAN PUSTAKA}

\section{Transfer Pelatihan}

Transfer pelatihan didefinisikan sejauh mana, pengetahuan, keahlian, dan perilaku belajar dalam pelatihan diterapkan dalam pekerjaan (Noe, et al., 2003). Menurut Baldwin \& Ford (1988) transfer pelatihan didefinisikan sebagai penerapan pengetahuan, keahlian dan perilaku yang dipelajari dalam pelatihan, diterapkan pada situasi kerja dan selanjutnya memeliharanya selama waktu tertentu. Tujuan akhir dari setiap program pelatihan adalah bahwa sistem pembelajaran yang terjadi selama pelatihan ditransfer kembali ke dalam pekerjaan. Transfer pelatihan (transfer of traning) adalah tingkat terhadap pengetahuan, keahlian, kemampuan atau karateristik lainnya yang dipelajari dalam pelatihan dapat diterapkan dalam pekerjaan. Transfer pelatihan yang efektif ditentukan oleh faktor-faktor yang disebut dengan input pelatihan. Artinya, input pelatihan merupakan berbagai faktor yang menentukan terjadinya transfer pelatihan. Scaduto et al. (2008), Velada et al., (2007), Burke and Hutchins (2008) serta Chiaburu and Marinova (2005) menyebutkan bahwa input pelatihan terdiri dari tiga faktor utama yaitu karakteristik individual, desain pelatihan dan lingkungan kerja. Masing-masing faktor tersebut terdiri dari berbagai dimensi utama. Dimensi karateristik individual antara lain adalah self-efficacy, motivasi mengikuti pelatihan dan orientasi pembelajaran. Dimensi desain pelatihan antara lain adalah retensi pelatihan dan desain pelatihan efektif. Dimensi lingkungan kerja antara lain adalah dukungan organisasional dan dukungan supervisor. 
Retensi pelatihan adalah tingkatan seberapa jauh peserta pelatihan mampu mempertahankan dan menguasai pengetahuan dan keterampilan yang telah diperolehnya setelah pelatihan (Baldwin and Ford, 1988). Artinya, peserta pelatihan tidak melupakan begitu saja materi pelatihan yang telah diperolehnya. Hal ini menjadi penting dalam keberhasilan proses transfer pelatihan karena individu memang dituntut untuk menguasai materi pelatihan tersebut. Peserta pelatihan diharapkan dapat memelihara materi pelatihan dalam jangka waktu tertentu, sehingga dapat diaplikasikan dalam pekerjaan sehari-hari.

Desain pelatihan berkaitan dengan penyusunan program pelatihan yang mempertimbangkan aspek organisasi, pekerjaan, dan individu. Desain pelatihan yang efektif berarti program pelatihan yang mampu menghasilkan outcomes berupa cognitive outcomes, skillbased outcomes, affective outcomes, dan reaction outcomes (Noe et al., 2003). Luaran kognitif berkaitan dengan ukuran seberapa jauh peserta pelatihan mampu menguasai prinsip, fakta, teknik, prosedur dan proses yang ditekankan dalam pelatihan. Ukuran kognitif ini menunjukan tingkat pemahaman peserta dalam mengikuti proses pembelajaran pada program pelatihan. Skill-based outcomes berkaitan dengan seberapa jauh peserta pelatihan menggunakan ketrampilan yang diperolehnya untuk pekerjaan sehari-hari. Manajer atau pengawas dapat mengetahui efek pelatihan dengan mengamati perilaku bawahannya, apakah ia menggunakan ketrampilan yang diperolehnya pada saat pelatihan atau tidak. Luaran afektif berkaitan dengan sikap individu terhadap fasilitas pelatihan, pelatih, dan materi pelatihan. Hal ini berkenaan dengan kenyamanan individu terhadap fasilitas pelatihan yang diperolehnya pada saat pelatihan, sikap positif terhadap pelatihnya dan kepuasan pada materi yang diperolehnya.

Dukungan organisasional adalah keyakinan karyawan tentang seberapa jauh organisasi memperhatikan kesejahteraan dan memberikan nilai bagi kontribusi yang telah diberikannya terhadap organisasi. Dukungan organisasional berkaitan dengan keinginan pihak manajemen untuk memberikan kompensasi terhadap berbagai usaha karyawannya, memberikan bantuan kesejahteraan, memberikan solusi permasalahan dalam pekerjaan, dan menjamin lingkungan kerja yang nyaman (Aube et al., 2007). Di sisi lain, dukungan pengawas adalah keyakinan karyawan tentang seberapa jauh pengawas memperhatikan kesejahteraan dan memberikan nilai bagi kontribusi yang telah diberikannya terhadap organisasi (Eisenberger et al, 2002). Dukungan organisasional memainkan peran yang penting dalam menentukan kinerja suatu pekerjaan karena berkaitan dengan terbentuknya komitmen individu, perilaku sosial dan kesejahteraan karyawan (Johlke et al., 2002). Selain itu, dukungan organisasional dan pengawas ini sangat menentukan keberhasilan transfer pelatihan karena sangat berkaitan dengan lingkungan kerja. Individu akan termotivasi untuk menggunakan ketrampilan dan pengetahuan baru yang diperolehnya apabila lingkungan kerjanya memang mendukungnya. Artinya, atasan dan pihak organisasi secara umum tidak bersikap antipati terhadap sesuatu hal yang baru dan mendukung sepenuhnya realisasi aplikasi keterampilan dan pengetahuan baru tersebut.

\section{Self-efficacy}

Self Efficacy adalah persepsi atau keyakinan tentang kemampuan diri sendiri. Menurut Noe et al. (2003) self efficacy adalah tingkat kepercayaan karyawan, bahwa mereka dapat berhasil mempelajari isi program pelatihan. Bandura (1991) menyatakan bahwa selfefficacy adalah kepercayaan seseorang bahwa dia dapat menjalankan sebuah tugas pada sebuah tingkat tertentu, yang mempengaruhi aktifitas pribadi terhadap pencapaian tujuan. Self efficacy merupakan keyakinan seseorang terhadap kemampuan dirinya melakukan sesuatu atau pekerjaan spesifik yang menjadi tanggung jawabnya.

Greenberg and Baron (2003) menyatakan bahwa self efficacy terdiri dari tiga komponen dasar yaitu: Magnitude, strength dan generality. Magnitude terkait dengan tingkat kepercayaan individu pada kemampuan dirinya. Strenght terkait dengan keyakinan seseorang terhadap kemampuannya untuk melakukan sesuatu pada level tertentu. Generality terkait dengan seberapa jauh self-efficacy yang dimiliki seseorang untuk pekerjaan dan situasi tertentu juga dapat berlaku untuk situasi dan pekerjaan yang lain. 
Albert Bandura sebagaimana yang diuraikan oleh Robbins and Judge (2011) menyebutkan empat faktor utama yang dapat digunakan untuk meningkatkan self-efficacy yaitu enactive mastery, vicarious modeling, verbal persuasion dan arousal. Enactive mastery berkenaan dengan kinerja individu sebelumnya yang akan berpengaruh pada kinerja individu selanjutnya dan akan meningkatkan keyakinan diri seseorang dalam menjalankan tugas spesifik lainnya. Vicarious modeling berkenaan dengan proses pembelajaran yang dilakukan individu dengan cara mengamati dan meniru orang lain serta mempelajari konsekuensi setiap perilaku yang akan dilakukan. Verbal persuasion berkenaan dengan interaksi antar individu yang saling menguatkan untuk melakukan pekerjaan dengan lebih baik. Individu akan semakin yakin bahwa dirinya dapat melakukan pekerjaan tertentu bila mendapat dukungan dari orang lain. Arousal berkenaan dengan keadaan yang membangkitkan energi yang dapat memicu seseorang untuk menyelesaikan suatu pekerjaan.

Pengembangan self-efficacy menurut Bandura (1991) menggambarkan empat sumber informasi mengarahkan ke kepercayaan-kepercayaan kemampuan: penguasaan aktif, pengalaman sebelumnya, persuasi dan pembangkitpembangkit fisiologis. Pengalaman menyediakan informasi langsung mengenai kemampuan memprediksi dan mengatasi ancamanancaman untuk membuktikan self-efficacy yang kuat. Peneliti menemukan bukti yang menunjukkan bahwa konsistensi sikap perilaku yang lebih kuat untuk orang-orang dengan pengalaman sebelumnya pada suatu objek, hal itu disebabkan oleh fakta bahwa mereka mempunyai kemampuan untuk mengakses informasi tentang perilaku mereka selama pengalaman tersebut (Davis et al, 2000). Demikian juga penelitian Colquitt (2000) menunjukkan bahwa self efficacy mempunyai hubungan yang kuat dengan motivasi belajar dan transfer. Self efficacy yang digeneralisasikan merepresentasikan sebuah kepercayaan seseorang tentang kemampuannya mencapai tujuan-tujuan dan mengatasi rintangan-rintangan. Sejalan dengan pendapat para ahli diatas, Davis et al (2000) menyatakan bahwa Self efficacy sebagai sebuah hasil penting proses pelatihan, yaitu lebih menekankan pada pengembangan self efficacy yang menggeneralisasi ke setting peralihan (atau fase-fase pelatihan berikutnya). Selanjutnya dalam penelitian ini peneliti memfokuskan pada self-efficacy yang menggeneralisasi (kondisi transfer) ke tempat kerja.

\section{Hipotesis Penelitian}

Gambar 1 menunjukan model transfer pelatihan efektif yang ditentukan oleh berbagai faktor yang meliputi desain pelatihan dan lingkungan kerja (Baldwin and Ford, 1988; Velada et al., 2007; Burke and Hutchins (2008). Scaduto, et al., (2008) menyatakan bahwa pelatihan yang efektif adalah fungsi dari desain pelatihan dan faktor kontekstual atau lingkungan kerja. Dimensi desain pelatihan adalah desain efektif dan retensi pelatihan, sedangkan dimensi lingkungan kerja adalah dukungan organisasi dan supervisor. Transfer pelatihan juga ditentukan oleh karakteristik individu, dalam hal ini selfefficacy menjadi penentu keefektifan transfer pelatihan (Chiaburu and Marinova, 2005; Chiaburu and Lindsay, 2008). Selain itu, gambar tersebut juga menjelaskan bahwa kedua faktor input pelatihan tersebut dapat meningkatkan self-efficacy yaitu keyakinan individu bahwa dirinya mampu menjalankan tugas yang menjadi tanggung jawabnya. Input pelatihan yang berupa desain efektif, retensi pelatihan, dukungan organisasi dan supervisor menjadi penentu self-efficacy. 


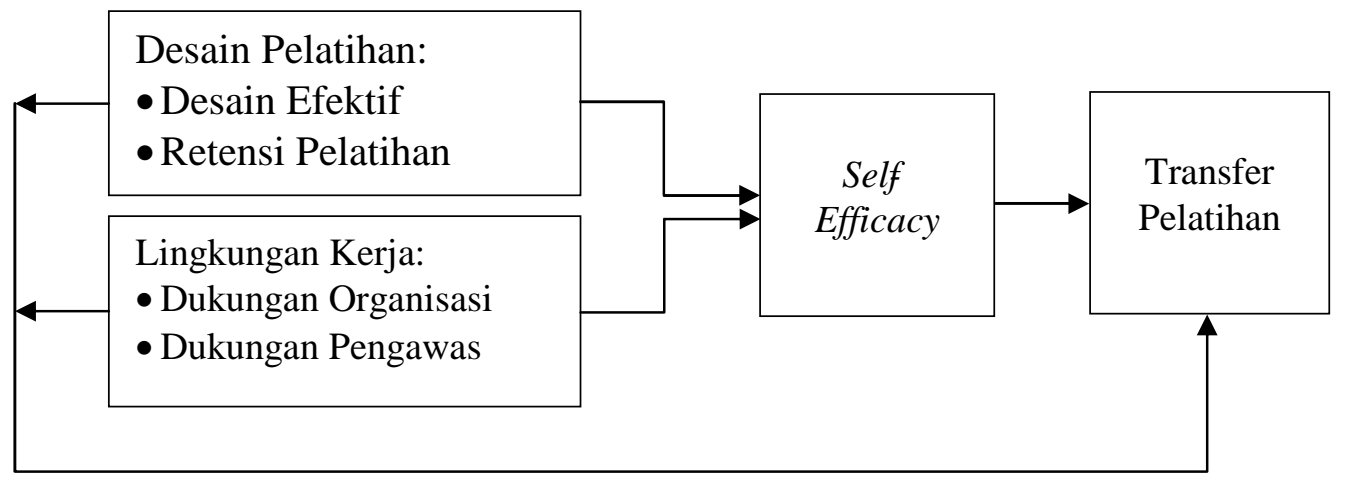

Gambar 1: Model Transfer Pelatihan Yang Efektif

Secara lebih terperinci, transfer pelatihan yang efektif ditentukan oleh desain pelatihan itu sendiri. Desain pelatihan yang efektif dan mampu menghasilkan luaran (outcomes) yang positif berupa luaran kognitif, luaran afektif, ketrampilan dan pengetahuan baru akan menentukan keberhasilan transfer pelatihan. Luaran kognitif itu menunjukan bahwa peserta pelatihan dapat menguasai dan memahami berbagai prinsip, fakta, prosedur dan proses yang diberikan pada saat pelatihan berlangsung. Luaran afektif menunjukan peningkatan motivasi dan terbentuknya sikap positif peserta selama dan setelah mengikuti pelatihan. Selain itu, desain pelatihan efektif juga menunjukan bahwa peserta pelatihan mampu memahami dan menggunakan ketrampilan baru dalam pekerjaan sehari-hari. Desain pelatihan juga berkaitan dengan retensi pelatihan yang menjamin bahwa materi pelatihan yang diperoleh peserta tetap dikuasainya dalam jangka waktu tertentu. Retensi pelatihan ini menunjukan kapasitas kemampuan seseorang dalam memahami dan memelihara materi pelatihan yang telah diperolehnya. Velada et al., (2007) menunjukan bahwa retensi pelatihan merupakan faktor penting yang menentukan terjadinya transfer pelatihan yang efektif. Intinya adalah bahwa desain pelatihan yang efektif akan mampu meningkatkan kinerja individual apabila hasil pelatihan yang berupa ketrampilan dan pengetahuan baru itu benar-benar direalisaskan dalam pekerjaan (Velada et al., 2007).

$\mathrm{H}_{1}$ : Desain pelatihan efektif dan retensi pelatihan akan berpengaruh signifikan dan positif terhadap transfer pelatihan

Lingkungan kerja yang diwarnai dengan adanya dukungan organisasional dan supervisor akan menentukan transfer pelatihan yang efektif. Saks and Belcourt (2006) menyatakan bahwa aktivitas untuk menciptakan kondisi lingkungan kerja yang kondusif untuk transfer pelatihan harus dilakukan sebelum proses pelatihan itu berlangsung. Artinya, pihak manajemen dan supervisor yang memberikan perhatian pada kesejahteraan, pekerjaan dan motivasi individu akan berdampak positif kepada keberhasilan proses transfer pelatihan. Pihak manajemen dan pengawas yang mendukung dan memberikan dorongan terhadap realisasi ketrampilan dan pengetahuan baru akan menentukan transfer pelatihan yang efektif. Tesluk $e t$ al., (1995) menyatakan bahwa manajer seharusnya aktif membangun iklim partisipasi individu dalam menentukan kebijakan terkait dengan pekerjaan, sehingga individu tersebut terdorong untuk menggunakan ketrampilan dan pengetahuannya dalam pekerjaan. Selain itu, sikap dan perilaku manajer yang terbuka terhadap sesuatu yang baru dan kreativitas bawahannya, yang merupakan salah satu bentuk dukungan kepada bawahannya akan menentukan keberhasilan transfer pelatihan yang efektif. Hasil riset yang dilakukan oleh Velada, et al., (2007) menunjukan bahwa dukungan organisasi dan pengawas terhadap aplikasi keterampilan dan pengetahuan baru akan mendorong individu untuk menerapkan ketrampilan dan pengetahuannya itu dalam pekerjaan. Demikian pula hasil riset yang dilakukan oleh Chiaburu and Marinova (2005) yang menunjukan bahwa transfer ketrampilan baru ke dalam pekerjaan ditentukan oleh dukungan pengawas.

$\mathrm{H}_{2}$ : Dukungan organisasional dan supervisor akan berpengaruh signifikan dan positif terhadap transfer pelatihan 
Self-efficacy merupakan bagian dari social cognitive theory atau social learning theory yang dikembangkan oleh Bandura (1991). Individu melakukan proses pembelajaran sebelum melakukan perilaku tertentu, mempelajari perilaku terdahulu, mempelajari perilaku orang lain dan memahami konsekuensi perilaku tersebut. Individu yang memiliki selfefficacy tinggi akan lebih mampu menunjukan kinerja yang baik dibandingkan dengan individu dengan self-efficacy rendah. Dalam konteks transfer pelatihan, individu dengan selfefficacy tinggi akan lebih bisa mengaplikasikan ketrampilan yang diperolehnya selama pelatihan dibandingkan dengan individu dengan selfefficacy rendah. Self-efficacy itu sendiri dapat dikembangkan dengan empat faktor utama yaitu enactive mastery, vicarious learning, verbal persuasion dan arousal (Robbins and Judge, 2011). Pelatihan yang diikuti oleh individu termasuk ke dalam faktor vicarious learning. Proses pelatihan memberikan individu berbagai ketrampilan dan pengetahuan yang dapat dilakukan untuk pekerjaan sehari-hari. Pelatih memberikan berbagai contoh pelaksanaan kerja teknis yang dapat dipelajari oleh peserta pelatihan. Proses pembelajaran dalam pelatihan ini akan meningkatkan self-efficacy individu dan dapat memicu realisasi transfer pelatihan. Hasil penelitian Tai (2006) menunjukan bahwa faktor kontekstual seperti pelatihan yang efektif dapat meningkatkan self-efficacy individu. Di sisi lain, self-efficacy juga dapat meningkat apabila individu mendapat dukungan dari orang lain (verbal persuasion). Dalam konteks pelatihan, self-efficacy individu untuk mentransfer hasil pelatihan yang diikutinya akan meningkat apabila mendapat dukungan dari atasan langsung dan manajemen organisasi. Hasil penelitian Pillai and Williams (2004) menunjukan bahwa pemimpin memiliki peran penting untuk meningkatkan self-efficacy individu. Pemimpin organisasi atau pun atasan langsung dapat memberikan motivasi, arahan, verbal persuasion, dan penguatan kepada individu dalam melakukan aktivitas dan pekerjaan tertentu sehingga mampu meningkatkan selfefficacy individu.

$\mathrm{H}_{3}$ : Desain pelatihan efektif dan retensi pelatihan akan berpengaruh signifikan dan positif terhadap self-efficacy
$\mathrm{H}_{4}$ : Dukungan organisasional dan pengawas akan berpengaruh signifikan dan positif terhadap self-efficacy

Self-efficacy merupakan keyakinan individu bahwa dirinya mampu melakukan suatu hal tertentu. Dalam konteks pelatihan, self-efficacy berarti keyakinan individu bahwa dirinya dapat mengaplikasikan berbagai pengetahuan dan ketrampilan yang telah diperolehnya selama pelatihan ke dalam pekerjaan sehari-hari. Individu yang memiliki selfefficacy tinggi akan lebih mampu melakukan transfer pelatihan dibandingkan dengan individu dengan self-efficacy rendah. Velada et al. (2008) serta Chiaburu and Marinova (2005) menyebutkan bahwa self-efficacy berkaitan erat dengan transfer ketrampilan yang diperolehnya selama pelatihan. Chiaburu and Lindsay (2008) juga menyatakan bahwa self-efficacy yang dimiliki peserta pelatihan memiliki peran penting dalam memunculkan distal outcomes seperti transfer pelatihan. Hal tersebut disebabkan karena individu dengan self-efficacy yang tinggi memiliki motivasi belajar yang tinggi selama pelatihan dan memiliki semangat untuk mengaplikasikan ketrampilan yang diperolehnya dari pelatihan yang diikutinya. Holton et al (2000) menyatakan bahwa individu dengan self-efficacy yang tinggi dapat mengubah kinerja sesuai dengan keinginan mereka sendiri. Artinya, apabila individu merasa yakin bahwa dirinya memiliki kemampuan berkinerja baik, maka semakin besar peluang untuk merealisasikan ketrampilan dan pengetahuan yang diperolehnya selama pelatihan.

$\mathrm{H}_{5}$ : Self-efficacy akan berpengaruh signifikan dan positif terhadap transfer pelatihan

\section{METODE PENELITIAN}

\section{Metode Pengambilan Sampel}

Metode pengambilan sampel yang digunakan adalah purposive sampling yang mana sampel penelitian dipilih dengan kriteria tertentu (Cooper \& Schindler, 2003), agar diperoleh sampel yang memadai sesuai dengan tujuan penelitian. Sampel penelitian diambil dari tenaga medis di rumah sakit umum daerah di 5 Kabupaten Provinsi Jawa Tengah. Pemilihan sampel kabupaten dalam penelitian ini karena dalam penelitian sebelumnya yang dilakukan oleh Mustofa dan Darmawan (2009) ditemukan 
mayoritas rumah sakit umum daerah mengalami permasalahan dalam proses pembelajaran internal yang berpengaruh pada proses pelayanan kepada konsumen.

Data yang diperlukan dalam penelitian ini adalah data primer. Metode pengumpulan data yang digunakan adalah metode survei dengan menggunakan kuesioner yang disebarkan kepada responden. Populasi penelitian ini adalah perawat di daerah eks Karesidenan Banyumas dengan sampel perawat di lima rumah sakit umum daerah. Metode pengambilan sampel yang digunakan adalah purposive sampling yang mana sampel penelitian dipilih dengan kriteria tertentu (Cooper \& Schindler, 2003). Kriteria sampel yang dijadikan responden adalah sudah bekerja minimal 2 tahun dan pernah mengikuti pelatihan yang diadakan manajemen rumah sakit minimal 2 kali. Pelatihan yang diikuti responden adalah pelatihan yang berkenaan dengan teknis pekerjaan dan digunakan dalam pelaksanaan kerja sehari-hari. Responden telah mengikuti peatihan setidaknya tiga bulan yang lalu sejak menerima kuesioner dari peneliti. Pelaksanaan pengumpulan data meliputi identifikasi calon responden, pengkodean, persiapan materi daftar pertanyaan dan distribusi kuesioner serta pengumpulan data.

\section{Variabel Penelitian dan Pengukuran}

Penelitian ini terdiri dari enam variabel. Variabel Independen terdiri desain pelatihan efektif, retensi pelatihan, dukungan organisasional dan dukungan pengawas. Variabel dependennya adalah transfer pelatihan, sedangkan self-efficacy sebagai variabel mediasi. Berikut ini adalah definisi operasional dan pengukuran masing-masing variabel tersebut.

\section{Transfer Pelatihan}

Transfer pelatihan didefinisikan sebagai penerapan pengetahuan, keahlian, dan perilaku yang dipelajari dalam pelatihan, diterapkan pada situasi kerja dan selanjutnya memeliharanya selama waktu tertentu (Baldwin and Ford, 1988). Dalam konteks RSUD, transfer pelatihan adalah realisasi hasil pelatihan yang telah diikuti oleh tenaga medis dalam bentuk penerapan pengetahuan, keahlian dan perilaku dalam pekerjaan sehari-hari. Pengukuran transfer pelatihan dilakukan dengan menggunakan lima butir pernyataan yang dikembangkan oleh Kaunzer (1986) dan ditambah dengan 3 butir pernyataan yang dikembangkan oleh Tesluk, et al., (1995). Pengukuran dilakukan dengan menggunakan skala likert $5(1=$ sangat tidak setuju; 2 = tidak setuju; $3=$ netral; $4=$ setuju, dan $5=$ sangat setuju).

\section{Self-efficacy}

Self efficacy adalah kepercayaan seseorang bahwa dia dapat menjalankan sebuah tugas pada tingkatan tertentu, yang mempengaruhi aktifitas pribadi terhadap pencapaian tujuan (Bandura, 1991). Dalam konteks RSUD, selfefficacy adalah keyakinan tenaga medis bahwa dirinya dapat merealisasikan hasil pelatihan dalam menjalankan tugas sehari-hari. Pengukuran self-efficacy dilakukan dengan menggunakan empat butir pernyataan yang dikembangkan oleh Holton, et al., (2000). Pengukuran ini juga digunakan oleh Velada, et al., (2007). Pengukuran dilakukan dengan menggunakan skala likert 5 ( $1=$ sangat tidak setuju; $2=$ tidak setuju; $3=$ netral; $4=$ setuju, dan $5=$ sangat setuju).

\section{Retensi Pelatihan}

Retensi pelatihan adalah tingkatan seberapa jauh peserta pelatihan mampu mempertahankan dan menguasai pengetahuan dan ketrampilan yang telah diperolehnya setelah pelatihan (Baldwin and Ford, 1988). Dalam konteks RSUD, retensi pelatihan terkait dengan kemampuan tenaga medis mempertahankan dan menguasai pengetahuan dan ketrampilan yang diperolehnya selama pelatihan. Pengukuran retensi pelatihan dilakukan dengan menggunakan tiga butir pernyataan yang dikembangkan oleh Velada, et al., (2007). Pengukuran dilakukan dengan menggunakan skala likert 5 ( $1=$ sangat tidak setuju; $2=$ tidak setuju; $3=$ netral; $4=$ setuju, dan $5=$ sangat setuju).

\section{Desain Pelatihan Efektif}

Desain pelatihan berkaitan dengan penyusunan program pelatihan yang mempertimbangkan aspek organisasi, pekerjaan, dan individu. Desain pelatihan yang efektif berarti program pelatihan yang mampu menghasilkan outcomes berupa cognitive outcomes, skill-based outcomes, affective outcomes dan reaction outcomes (Noe, et al., 2003). Dalam konteks 
RSUD, program pelatihan dinyatakan efektif apabila peserta pelatihan memperoleh berbagai manfaat pelatihan yang dapat dilihat dari aspek kognitif, aspek ketrampilan, aspek afeksi dan aspek reaksi. Pengukuran variabel ini dilakukan dengan menggunakan beberapa butir pernyataan yang mengacu pada aspek-aspek tersebut. Pengukuran dilakukan dengan menggunakan skala likert 5 ( 1 = sangat tidak setuju; $2=$ tidak setuju; $3=$ netral; $4=$ setuju, dan $5=$ sangat setuju).

\section{Dukungan Organisasional}

Dukungan organisasional adalah keyakinan karyawan tentang seberapa jauh organisasi memperhatikan kesejahteraan dan memberikan nilai bagi kontribusi yang telah diberikannya terhadap organisasi (Eisenberger, 1986). Dalam konteks RSUD, dukungan organisasional terkait dengan perhatian pihak manajemen rumah sakit terhadap kesejahteraan para tenaga medis dan penghargaan terhadap kontribusi tenaga medis. Pengukuran dukungan organisasonal dilakukan dengan menggunakan delapan butir pernyataan yang dikembangkan oleh Eisenberger (1990). Pengukuran dilakukan dengan menggunakan skala likert $5(1=$ sangat tidak setuju; 2 = tidak setuju; $3=$ netral; $4=$ setuju, dan $5=$ sangat setuju).

\section{Dukungan Pengawas}

Dukungan pengawas adalah keyakinan karyawan tentang seberapa jauh supervisor memperhatikan kesejahteraan dan memberikan nilai bagi kontribusi yang telah diberikannya terhadap organisasi (Eisenberger et al., 2002). Dalam konteks RSUD, dukungan pengawas terkait dengan perhatian pengawas atau atasan langsung terhadap kesejahteraan para tenaga medis dan penghargaan terhadap kontribusi tenaga medis. Pengukuran dukungan pengawas dilakukan dengan menggunakan delapan butir pernyataan yang dikembangkan oleh Eisenberger (1990). Pengukuran dilakukan dengan menggunakan skala likert $5(1=$ sangat tidak setuju; $2=$ tidak setuju; $3=$ netral; $4=$ setuju, dan $5=$ sangat setuju).

\section{Analisis Data}

Uji validitas dilakukan untuk menguji kesesuaian instrumen penelitian (item pertanyaan atau pernyataan) dengan konstruk yang akan diukur (Sekaran, 2003). Instrumen dinyatakan valid bila item yang digunakan benar-benar mewakili konstruk yang akan diukur. Apabila instrumen dinyatakan valid berarti alat ukur yang digunakan dalam penelitian sudah tepat. Uji validitas yang digunakan dalam penelitian ini adalah analisis faktor konfirmatori.

Uji reliabilitas dilakukan untuk menguji konsistensi instrumen penelitian. Suatu alat ukur dinyatakan reliable atau handal ketika menghasilkan pengukuran yang konsisten pada kondisi yang berbeda (Cooper \& Schindler, 2003). Reliable berarti dengan alat ukur yang sama, dan gejala yang sama, tetapi pada kondisi dan situasi yang berbeda, pengukuran menunjukkan hasil yang konsisten. Alat uji yang biasa dan populer digunakan adalah uji konsistensi internal (internal consistency) dengan menggunakan koefisien cronbach alpha. Tingkat koefisien yang disarankan adalah 0,7 (Hair et al., 1998) atau 0,6 (Nunnaly, 1978). Sekaran (2003) mengklasifikasikan tingkat koefisien reliabilitas menjadi tiga: koefisien cronbach alpha kurang dari 0,6 menandakan reliabilitas yang kurang baik, cronbach alpha 0,6 sampai dengan 0,8 menandakan tingkat reliabilitas yang dapat diterima, dan cronbach alpha lebih dari 0.8 menandakan reliabilitas yang baik.

Untuk menguji hipotesis digunakan analisis regresi berganda. Langkah pertama menguji pengaruh desain pelatihan efektif dan retensi pelatihan terhadap transfer pelatihan (H1). Langkah kedua menguji pengaruh desain efektif dan retensi pelatihan terhadap transfer pelatihan (H2). Langkah ketiga menguji pengaruh desain efektif dan retensi pelatihan terhadap self-efficacy (H3). Langkah keempat menguji pengaruh dukungan organisasional dan supervisor terhadap self-efficacy (H4). Langkah kelima menguji pengaruh self-efficacy terhadap transfer pelatihan (H5).

\section{HASIL ANALISIS}

\section{Profil Responden}

Sampel penelitian ini adalah perawat yang berada di lima rumah sakit umum daerah yaitu RSUD Purbalingga, RSUD Banjarnegara, RSUD Majenang, RSUD Ajibarang, dan RSUD Kebumen. Jumlah kuesioner masing-masing rumah sakit adalah: RSUD Purbalingga 133 kuesioner, RSUD Banjarnegara 164 kuesioner, 
RSUD Majenang 93 kuesioner, RSUD Ajibarang 120 kuesioner, dan RSUD Kebumen 120 kuesioner. Jadi, secara keseluruhan ada 630 kuesioner yang disebar. Kuesioner yang terisi sejumlah 491 buah atau response rate sebesar 77,94 persen. Jumlah kuesioner yang lengkap sesuai dengan kriteria sampel dan digunakan olah data adalah 346 kuesioner atau 70,46 persen dari jumlah kuesioner terisi.

Jenis kelamin responden terdiri dari 28,5 persen laki-laki dan 71,5 persen perempuan. Jumlah perempuan memang lebih banyak karena responden adalah perawat yang merupakan pekerjaan yang didominasi oleh perempuan. Usia responden terdiri dari 22,8 persen berusia kurang dari 25 tahun, 66 persen berusia 26-40 tahun, dan 11,2 persen berusia lebih dari 40 tahun. Jumlah responden yang berpendidikan SMA atau sederajat adalah 3,3 persen, diploma 85,9 persen dan sarjana 10,8 persen. Pengalaman kerja responden sebagai perawat antara 1-10 tahun adalah 86,2 persen dan di atas 10 tahun adalah 13,8 persen. Rata-rata responden sudah pernah mengikuti pelatihan yang bersifat teknis sebanyak 2-4 kali.

Uji validitas dilakukan untuk menguji kesesuaian instrumen penelitian (item pertanyaan atau pernyataan) dengan konstruk yang akan diukur (Sekaran, 2003). Instrumen dinyatakan valid bila item yang digunakan benar-benar mewakili konstruk yang akan diukur. Masing-masing item pernyataan yang sudah dianggap valid tersebut adalah 12 item untuk mengukur desain pelatihan efektif, 3 item untuk mengukur retensi pelatihan, 8 item untuk mengukur dukungan organisasional, 8 item untuk mengukur dukungan pengawas, 4 item untuk mengukur self-efficacy, dan 8 item untuk mengukur transfer pelatihan. Jadi, ada 43 item pernyataan yang dianggap valid dan dapat digunakan untuk analisis data selanjutnya yaitu uji reliabilitas.
Uji reliabilitas dilakukan untuk menguji konsistensi instrumen penelitian. Alat uji yang biasa dan populer digunakan adalah uji konsistensi internal (internal consistency) dengan menggunakan koefisien cronbach alpha. Tabel 1 menunjukan ringkasan hasil uji reliabilitas terhadap 43 item pernyataan yang sudah dianggap valid pada tahap sebelumnya. Berdasarkan hasil statistik tersebut, semua pernyataan yang berjumlah 43 item dianggap reliabel atau handal untuk mengukur variabel tertentu. Masing-masing jumlah item per variabel yang dianggap reliabel adalah sebagai berikut: 12 item untuk mengukur desain pelatihan efektif, 3 item untuk mengukur retensi pelatihan, 8 item untuk mengukur dukungan organisasional, 8 item untuk mengukur dukungan pengawas, 4 item untuk mengukur self-efficacy, dan 8 item untuk mengkur transfer pelatihan. Jadi, ada 43 item pernyataan yang dianggap reliabel dan dapat digunakan untuk analisis data selanjutnya yaitu statistik deskriptif dan uji hipotesis.

Namun demikian, kalau kita lihat lebih cermat, ada item pernyataan yang koofesien reliabilitasnya dianggap kurang baik karena berada di bawah 0,6 yaitu item-item pernyataan pada variabel retensi pelatihan (koofesien 0,458). Variabel ini tetap digunakan untuk analisa selanjutnya, meskipun memiliki reliabilitas yang kurang baik, karena koofesien rendah merupakan hal wajar pada variabel dengan jumlah item yang sedikit. Dalam hal ini variabel retensi pelatihan hanya diukur dengan menggunakan 3 item pernyataan saja.

\section{Hasil Pengujian Hipotesis}

Analisis regresi berganda digunakan sebagai alat analisis untuk menguji lima hipotesis dalam penelitian ini. Tabel 2 menunjukan ringkasan hasil uji kelima hipotesis dengan koefisien regresi $(\beta)$ dan tingkat signifikansinya.

Tabel 1: Ringkasan Hasil Uji Reliabilitas

\begin{tabular}{lccc}
\hline \multicolumn{1}{c}{ Nama Variabel } & Jumlah Item & Koofesien & Keterangan \\
\hline Desain Pelatihan Efektif & 12 & 0,934 & Baik \\
Retensi Pelatihan & 3 & 0,458 & Kurang Baik \\
Dukungan Organisasional & 8 & 0,791 & Diterima \\
Dukungan Pengawas & 8 & 0,785 & Diterima \\
Self efficacy & 4 & 0,772 & Diterima \\
Transfer Pelatihan & 8 & 0,891 & Baik \\
\hline
\end{tabular}

Sumber: Lampiran (data primer yang diolah, 2010) 
Tabel 2: Ringkasan Hasil Uji Regresi

\begin{tabular}{lcc}
\hline \multicolumn{1}{c}{ Variabel } & \multicolumn{2}{c}{ Variabel Dependen } \\
\hline Variabel Independen: & \multicolumn{1}{c}{ Self-efficacy } & Transfer Pelatihan \\
\cline { 2 - 3 } Desain Efektif & $\mathbf{(})$ & $(\boldsymbol{\beta})$ \\
Retensi Pelatihan & $0,278^{* * *}$ & $0,485^{* * *}$ \\
Dukungan Organisasi & $0,103^{*}$ & $0,178^{* * *}$ \\
Dukungan Supervisor & $-0,005$ & $-0,065$ \\
Self efficacy & 0,087 & $-0,016$ \\
\hline
\end{tabular}

Keterangan: $* \mathrm{p}<0,1 * * \mathrm{p}<0,01 * * * \mathrm{p}<0,001$

\section{Hipotesis 1}

Hipotesis satu digunakan untuk menguji pengaruh desain pelatihan efektif dan retensi pelatihan terhadap transfer pelatihan. Berdasarkan hasil analisa regresi dapat dilihat bahwa desain pelatihan efektif memiliki pengaruh signifikan dan positif terhadap transfer pelatihan $(\beta=$ $0.458, \mathrm{p}<0.001$ ) dan retensi pelatihan juga memiliki pengaruh signifikan dan positif terhadap transfer pelatihan $(\beta=0.178, \mathrm{p}<0.001)$. Hal ini menunjukan bahwa hipotesis 1 didukung. Artinya, keberhasilan tenaga medis untuk merealisasikan dan menggunakan materi pelatihan yang pernah diperolehnya dalam pekerjaan sehari-hari, sangat ditentukan oleh desain pelatihan yang sesuai dengan kebutuhan tenaga medis. Selain itu, kemampuan tenaga medis untuk tetap ingat dengan materi pelatihan yang pernah diikutinya juga akan menentukan keberhasilan transfer pelatihan.

\section{Hipotesis 2}

Hipotesis dua digunakan untuk menguji pengaruh dukungan organisasional dan dukungan supervisor terhadap transfer pelatihan. Berdasarkan hasil analisa regresi dapat dilihat bahwa dukungan organisasional tidak memiliki pengaruh signifikan terhadap transfer pelatihan $(\beta=-0.065, p>0.1)$ dan dukungan supervisor juga tidak memiliki pengaruh signifikan transfer pelatihan $(\beta=-0.016, p>0.1)$. Hal ini menunjukan bahwa hipotesis 2 tidak didukung. Artinya, perhatian pihak manajemen dan atasan langsung pada permasalahan dan kesejahteraan tenaga medis tidak menentukan keberhasilan transfer pelatihan. Selain itu, hasil analisis regresi tersebut menunjukan bahwa jumlah pelatihan yang diikuti oleh tenaga medis memiliki pengaruh signifikan terhadap transfer pelatihan $(\beta=0.153, \mathrm{p}<0.01)$. Artinya, semakin banyak pelatihan yang diikuti oleh tenaga medis akan semakin besar terjadinya transfer pelatihan.

\section{Hipotesis 3}

Hipotesis tiga digunakan untuk menguji pengaruh desain pelatihan efektif dan retensi pelatihan terhadap self-efficacy. Berdasarkan hasil analisa regresi dapat dilihat bahwa desain pelatihan efektif memiliki pengaruh signifikan dan positif terhadap self-efficacy $(\beta=0.278$, $\mathrm{p}<0.001)$ dan retensi pelatihan juga memiliki pengaruh signifikan dan positif terhadap transfer pelatihan $(\beta=0.103, \mathrm{p}<0.1)$. Hal ini menunjukan bahwa hipotesis 3 didukung. Artinya, keyakinan tenaga medis untuk melakukan pekerjaan yang menjadi tanggung jawabnya, sangat ditentukan oleh desain pelatihan yang sesuai dengan kebutuhan tenaga medis. Selain itu, kemampuan tenaga medis untuk tetap ingat dengan materi pelatihan yang pernah diikutinya juga akan menentukan selfefficacy individu.

\section{Hipotesis 4}

Hipotesis empat digunakan untuk menguji pengaruh dukungan organisasional dan dukungan supervisor terhadap self-efficacy. Berdasarkan hasil analisa regresi dapat dilihat bahwa dukungan organisasional tidak memiliki pengaruh signifikan terhadap self-efficacy ( $\beta=$ $-0.055, \mathrm{p}>0.1$ ) dan dukungan supervisor juga tidak memiliki pengaruh signifikan self-efficacy $(\beta=0.087, p>0.1)$. Hal ini menunjukan bahwa hipotesis 4 tidak didukung. Artinya, perhatian pihak manajemen dan atasan langsung pada permasalahan dan kesejahteraan tenaga medis tidak menentukan self-efficacy seseorang. Selain itu, hasil analisis regresi tersebut menunjukan bahwa jumlah pelatihan yang 
diikuti oleh tenaga medis memiliki pengaruh signifikan terhadap transfer pelatihan $(\beta=$ 0.183 , p <0.01). Artinya, semakin banyak pelatihan yang diikuti oleh tenaga medis akan semakin besar terjadinya transfer pelatihan.

\section{Hipotesis 5}

Hipotesis lima digunakan untuk menguji pengaruh self-efficacy terhadap transfer pelatihan. Berdasarkan hasil analisa regresi dapat dilihat bahwa self-efficacy memiliki pengaruh signifikan dan positif terhadap transfer pelatihan $(\beta=0.316, \mathrm{p}<0.001)$. Hasil ini menunjukan bahwa hiptosis 5 didukung. Artinya, realisasi dan pemanfaatan ketrampilan hasil pelatihan dalam pekerjaan sehari-hari sangat ditentukan oleh keyakinan diri individu untuk melakukan pekerjaan tertentu.

\section{PEMBAHASAN}

Program pelatihan bagi sebuah organisasi merupakan investasi jangka panjang terhadap sumberdaya manusia yang dimilikinya. Efek yang dihasilkan dari pelatihan tidak langsung dapat dirasakan hasilnya bagi organisasi, karena pelatihan yang diperoleh oleh individu membutuhkan waktu untuk direalisasikan dalam pekerjaan sehari-hari. Realisasi hasil pelatihan tersebut ke dalam pekerjaan seharihari disebut dengan transfer pelatihan. Artinya, individu yang telah mengikuti pelatihan dianggap paham, ingat, dan mampu melaksanakan berbagai materi pelatihan yang telah diperolehnya. Apabila individu di dalam organisasi melakukan realisasi pelatihan tersebut berarti ada efektivitas transfer pelatihan. Transfer pelatihan yang efektif ini dalam jangka panjang akan menjadi pemicu utama untuk mencapai peningkatan produktivitas tenaga kerja (Chiaburu dan Lindsay, 2008; Burke and Hutchins, 2008).

Tujuan umum penelitian ini adalah untuk menguji beberapa faktor yang menjadi penentu transfer pelatihan yang efektif, khususnya bagi tenaga kerja di sektor kesehatan. Berdasarkan kajian teoritis transfer pelatihan efektif ditentukan oleh dua aspek utama yaitu desain pelatihan dan lingkungan kerja. Desain pelatihan terdiri dari dua dimensi yaitu desain efektif dan retensi pelatihan; lingkungan kerja terdiri dari dukungan supervisor dan dukungan organisasional. Keempat faktor ini, selain men- jadi penentu transfer pelatihan efektif, juga menjadi penentu self-efficacy individu. Selfefficacy yang merupakan keyakinan individu untuk melakukan suatu pekerjaan tertentu juga akan menjadi penentu transfer pelatihan yang efektif.

Hasil pengujian hipotesis dengan menggunakan analisa regresi menunjukan bahwa transfer pelatihan yang efektif ditentukan oleh faktor-faktor desain pelatihan efektif, retensi pelatihan dan self-efficacy. Hasil penelitian ini mendukung penelitian sebelumnya yang dilakukan dengan setting organisasi bisnis milik swasta (Velada et al., 2008; Scaduto et al., 2007; Chiaburu and Marinova, 2005). Hasil pengujian dalam penelitian ini menunjukan bahwa retensi pelatihan dan desain pelatihan efektif menjadi penentu transfer pelatihan yang efektif. Retensi pelatihan adalah tingkatan seberapa jauh peserta pelatihan mampu mempertahankan dan menguasai pengetahuan dan keterampilan yang telah diperolehnya setelah pelatihan. Artinya, keefektifan transfer pelatihan sangat ditentukan oleh kemampuan individu menyerap, memahami, dan mengingat materi pelatihan yang telah diperolehnya. Pemahaman dan kemampuan mempertahankan pengetahuan yang telah diperoleh individu dalam pelatihan tentu menjadi faktor penting keberhasilan realisasi pengetahuan tersebut dalam pekerjaan sehari-hari. Selain itu, desain pelatihan efektif juga menjadi penentu kefektifan transfer pelatihan. Beberapa indikator desain pelatihan yang efektif antara lain adalah: materi yang diajarkan dan proses pembelajaran yang digunakan sesuai dengan kebutuhan kerja para tenaga medis, pelatihan yang dilakukan mengajarkan ketrampilan baru dan dapat mendorong peserta pelatihan untuk mengaplikasikan ketrampilan baru tersebut dalam pekerjaan sehari-hari, pemateri atau pelatih yang digunakan dalam pelatihan dapat mendorong semangat kerja peserta dan fasilitas selama pelatihan dapat memenuhi kebutuhan peserta pelatihan (Noe et al., 2003). Artinya, manajemen rumah sakit sebaiknya memperhatikan indikator-indikator tersebut dalam mendesain pelatihan yang akan dilaksanakan karena memang secara empiris menunjukan bahwa desain pelatihan efektif menentukan keberhasilan transfer pelatihan yang efektif pula.

Selain faktor desain pelatihan yang terdiri dari retensi pelatihan dan desain efektif, 
faktor penting yang juga menjadi penentu transfer pelatihan efektif adalah self-efficacy. Penelitian ini mendukung hasil penelitian sebelumnya yang menyatakan bahwa keefektifan transfer pelatihan ditentukan oleh self-efficacy (Velada et al., 2007; Holton et al., 2000; Chiaburu and Marinova, 2005). Self-efficacy merupakan keyakinan seseorang terhadap kemampuan dirinya untuk melakukan sesuatu atau pekerjaan spesifik yang menjadi tanggung jawabnya. Berkaitan dengan transfer pelatihan, self-efficacy adalah keyakinan diri seseorang akan kemampuannya untuk merealisasikan hasil pelatihan yang telah diikutinya. Individu dengan self-efficacy adalah individu yang selalu berpikir positif dan yakin akan kemampuan yang dimilikinya dalam menjalankan tugas dan kewajibannya. Jadi, transfer pelatihan akan efektif, aplikasi dan realisasi hasil pelatihan akan terjadi, apabila rumah sakit memiliki tenaga medis dengan self-efficacy yang tinggi.

Penelitian ini juga mendukung hasil penelitian Tai (2006) yang menunjukan bahwa self-efficacy ditentukan oleh retensi pelatihan dan desain pelatihan efektif. Artinya, individu yang mampu memahami dan mempertahankan materi pelatihan dalam jangka waktu tertentu juga akan cenderung memiliki self-efficacy yang tinggi. Individu akan merasa siap karena dia sudah merasa cukup dengan bekal pengetahuan dan ketrampilan yang telah diperolehnya selama pelatihan. Self efficacy tidak hanya terbentuk dari dalam diri individu seperti motivasi dan kemampuan memahami pengetahuan, tapi juga bisa berasal dari faktor eksternal individu seperti desain pelatihan efektif. Artinya, self-efficacy bukanlah harga mati bagi individu tertentu yang memiliki karakteristik terentu. Self-efficacy dapat dibentuk dengan menciptakan lingkungan kerja dan pelatihan yang kondusif. Desain pelatihan efektif adalah desain pelatihan yang mampu mendorong dan memotivasi individu untuk belajar dan mengaplikasikan ketrampilan dan pengetahuan baru yang diperolehnya, sehingga dapat memunculkan rasa percaya diri bagi individu dalam melakukan tugasnya sehari-hari. Desain pelatihan efektif juga mengajarkan pengetahuan dan ketrampilan baru sehingga individu yakin dalam menyelesaikan permasalahan yang dihadapi dalam pekerjaannya.

Jadi, pada intinya, model transfer pelatihan yang efektif sebaiknya mempertimbang- kan aspek desain pelatihan dan keyakinan diri individu. Desain pelatihan yang perlu dipertimbangkan adalah retensi pelatihan dan desain yang efektif. Apabila keempat faktor ini diperhatikan dan menjadi pertimbangan dalam membuat kebijakan yang terkait pelatihan, maka self-efficacy individu juga akan terbentuk dan akan sangat membantu terciptanya transfer pelatihan yang efektif.

\section{PENUTUP}

Tujuan utama penelitian ini adalah untuk menguji faktor-faktor yang menjadi anteseden transfer pelatihan yang meliputi karakteristik individu (self-efficacy), lingkungan kerja (dukungan organisasi dan supervisor), dan desain pelatihan (desain efektif dan retensi pelatihan). Hasil penelitian menunjukan bahwa transfer pelatihan ditentukan oleh desain efektif, retensi pelatihan dan self-efficacy.

Oleh karena itu, Manajemen rumah sakit sebaiknya mempertimbangkan beberapa hal dalam menyusun program pelatihannya agar menjadi efektif, yaitu: materi yang diajarkan dalam pelatihan harus sesuai dengan kebutuhan kerja tenaga medis atau pengiriman tenaga medis untuk mengikuti pelatihanpelatihan baik di internal maupun eksternal rumah sakit sebaiknya mempertimbangkan aspek kebutuhan rumah sakit; teknik pelatihan dan proses pembelajaran yang digunakan juga sebaiknya sesuai dengan kebutuhan tenaga medis dan dapat mendorong tenaga medis untuk semangat mengikuti pelatihan serta terpacu mengaplikasikan hasil penelitiannya di dalam pekerjaan sehari-hari; presenter dan pemateri pun sebaiknya dipilih yang sesuai dengan kompetensinya dan mampu mendorong peserta pelatihan untuk dapat bekerja lebih baik dan lebih produktif; pelatihan yang efektif adalah juga pelatihan yang mampu meningkatkan komitmen para peserta pelatihan terhadap pekerjaan dan tanggung jawabnya di rumah sakit; adanya metode evaluasi untuk menilai seberapa jauh pelatihan yang diadakan oleh rumah sakit atau diikuti oleh tenaga medis dapat bermanfaat untuk peningkatan kinerja individu dan rumah sakit.

Manajemen rumah sakit juga sebaiknya mempertimbangkan program tertentu agar para tenaga medis tidak melupakan materi yang telah dipelajarinya di dalam pelatihan. Dengan 
kata lain manajemen rumah sakit sebaiknya memiliki kebijakan agar retensi pelatihan tetap terjaga selama jangka waktu tertentu. Manajemen rumah sakit dapat mewajibkan peserta pelatihan untuk melakukan sharing dengan rekan kerjanya di unit kerja masing-masing, sehingga materi pelatihan yang telah diperolehnya tidak hilang begitu saja dan dapat bermanfaat untuk unit kerjanya. Manajemen rumah sakit juga dapat menyarankan kepada tenaga medis yang telah mengikuti pelatihan untuk membuat laporan hasil pelatihan yang telah diikutinya dan melakukan evaluasi terhadap tenaga medis tersebut. Tujuan evaluasi tersebut adalah untuk mengetahui seberapa jauh efek positif dari pelatihan yang telah diikuti para tenaga medis.

\section{Saran Penelitian Selanjutnya}

Faktor yang menentukan keefektifan transfer pelatihan tidak hanya terbatas pada selfefficacy, retensi pelatihan, dan desain pelatihan efektif. Banyak faktor lain yang dapat menentukan keefektifan transfer pelatihan. Karakteristik individu yang dapat dikaitkan antara lain adalah kepribadian dengan pendekatan the big five, locus of control, learning orientation dan motivasi pelatihan. Lingkungan kerja lain yang dapat dikaji antara lain adalah dukungan rekan kerja, iklim kerja, dan hubungan atasanbawahan (leader member exchange). Selain itu, faktor sikap kerja seperti komitmen organisasional, kepuasan kerja dan keadilan organisasional juga dapat dipertimbangkan untuk penelitian selanjutnya sebagai anteseden transfer pelatihan. Penelitian selanjutnya yang juga menarik untuk diuji adalah konsekuen transfer pelatihan itu sendiri. Misalnya, menguji pengaruh transfer pelatihan terhadap kinerja individu, tim atau pun organisasi. Berbagai faktor tersebut dapat digunakan untuk penelitian selanjutnya agar dapat diperoleh model transfer pelatihan yang lebih komprehensif. Selain itu, penelitian selanjutnya dapat melakukan penelitian dengan setting organisasi publik yang berbeda seperti instansi pemerintah atau badan usaha milik pemerintah. Penelitian selanjutnya juga dapat mempertimbangkan faktor situasional dan disposisional yang dapat menguatkan atau melemahkan pengaruh variabel anteseden terhadap transfer pelatihan. Faktor situasional dan disposisional biasanya diperlakukan se- bagai variabel pemoderasian. Contoh faktor situasional yang dapat dikaji lebih lanjut antara lain adalah budaya organisasi, struktur organisasi, dan iklim kerja. Faktor disposisional yang dapat dikaji lebih lanjut antara lain adalah negative affectivity dan positive affectivity.

\section{DAFTAR PUSTAKA}

Aube, C., V. Rousseau and EM. Morin. 2007. Perceived Organizational Support and Organizational Commitment: The Moderating Effect of Locus of Control and Work Autonomy. Journal of Managerial Psychology. 22: 479-495.

Baldwin, T. and K. Ford. (1988). Transfer of Training: Review and Directions for Future Research. Personnel Psychology. 41: 63-105.

Bandura, A. 1986. Social foundations of thought and action: A social cognitive theory. Englewood Cliffs. NJ: Prentice Hall.

Bandura, A. 1991. Social Cognitive Theory of Self Regulation. Organizational Behavior and Human Decision Processes. 50: 248-287.

Burke, LA. and TT. Baldwin. 1999. Workforce Training Transfer: a Study of the Effect of Relapse Prevention Training and Transfer. Human Resource Management. 38: 227-43.

Burke, LA. and HM. Hutchins. 2008. A Study of Best Practices in Training Transfer and Proposed Model of Transfer. Human Resource Development Quarterly. 19: 107-128.

Chiaburu, DS. and DR. Lindsay. 2008. Can do or will do? The Importance of Self efficacy and Instrumentality for Training Transfer. Human Resource Development International. 11: 199-206.

Chiaburu, DS. and SV. Marinova, 2005. What Predicts Skill Transfer? An Exploratory Study of Goal Orientation, Training Self efficacy and Organizational Supports. International Journal of Training and Development. 9: 110-123. 
Colquitt, JA., JA. LePine and RA. Noe. 2000. Toward an Integrative Theory of Training Motivation: a Meta-analytic Path Analysis of 20 Years of Research. Journal of Applied Psychology. 85: 679-707.

Cooper, DR. and P.S., Schindler. 2003. Business Research Methods, $8^{\text {th }}$ ed, McGraw Hill: New York

Davis WD., DB. Fedor, CK. Parsons and MH. David. 2000. The Development of Selfefficacy During Aviation Training. Journal of Organizanional Behavior. 21: 857-871.

Eisenberger, R.. 2002. Perceived Supervisory Support: Contributions to Perceived Organizational Support and Employee Retention. Journal of Applied Psychology. 87: 565-573.

Facteau, JD., GH. Dobbins, JEA. Russell, RT. Ladd and J.D. Kudisch. 1995. The Influence of General Perceptions of the Training Environment on Pretraining Motivation and Perceived Transfer of Training. Journal of Management. 21: $1-25$.

Greenberg, J and RA. Baron, 2003. Behavior in Organizations: Understanding and Managing the Human Side of Work, $8^{\text {th }}$ edition, Prentice Hall International: New Jersey

Hair, J., F. Andersen, E. Rolph, Tatham, L. Ronald, Black and C. William. 1998. Multivariate Data Analysis, $5^{\text {th }}$ edition, Prentice-Hall: New Jersey

Holton, EF., RA. Bates and WEA. Ruona, 2000. Development of a Generalized Learning Transfer System Inventory. Human Resource Development Quarterly. 11: 333-60.

Johlke, MC., CL. Stamper dan ME. Shoemaker, 2002. Antecedents to BoundarySpanner Perceived Organizational Support. Journal of Managerial Psychology. 17: 116-128.

Kang, D. 2007. Perceived Organisational Justice as a Predictor of Employees' Motivation to Participate in Training.
Research and Practice in Human Resource Management. 15: 89-107.

Mustofa, RM. dan AB. Darmawan, 2009. Laporan Penelitian Hibah Kompetitif Sesuai Prioritas Nasional, Sumber dana Dikti, Tidak Dipublikasikan

Noe, RA., JR. Hollenbeck, B. Gerhart and PM. Wright, 2003. Human Resource Management: Gaining A Competitive Advantage. McGraw-Hill: New York

Pillai, R. and EA. Williams, 2004. Transformational Leadership, Self-efficacy, Group Cohesiveness, Commitment and Performance. Journal of Organizational Change Management.17: 144-159.

Robbins, SP. and TA. Judge. 2011. Organizational Behavior, $14^{\text {th }}$ edition, Pearson: New Jersey

Saks, AM. and M. Belcourt. 2006. An Investigation of Training Activities and Transfer of Training in Organizations. Human Resource Management. 45: 629-648.

Scaduto, A., D. Lindsay and DS. Chiaburu. 2008. Leader Influences on Training Effectiveness: Motivation and Outcome Expectation Processes. International Journal of Training and Development. 12: 158-170.

Sekaran, U. 2003. Research Methods for Business: A Skill-Building Approach. Fourth edition, John Wiley and Sons, Inc: New York

Tai, Wei-Tao. 2006. Effects of Training Framing, General Self-efficacy and Training Motivation on Trainees' Training Effectiveness. Personnel Review. 35: 51-65.

Tesluk, PE., JL. Farr., JE. Mathieu and R.J Vance. 1993. Generalization of Employee Involvement Training to the Job Setting: Individual and Situational Effects. Personnel Psychology. 48: 607632.

Velada R., A. Caetano, JW. Michel, BD. Lyons, M.J. Kavanagh. 2007. The effects of training design, individual characteristics and work environment 
on transfer of training. International Journal of Training and Development. 4: 282-294.
Wood, R.E. and A. Bandura. 1989. Social Cognitive Theory of Organizational Management. Academy of Management Review. 14: 361-384. 